\title{
Talking liberties: John Rawls's theory of justice and psychiatric practice ${ }^{\dagger}$
}

\author{
George Ikkos, Jed Boardman \& Tony Zigmond
}

Abstract Scarcity of resources compared with need results in resource-allocation decisions that will have a beneficent effect on some clinical populations and will be detrimental to others. Political philosophy, through theories of social justice, aims to establish generally applicable principles to guide such decisionmaking. We introduce here the work of the foremost liberal political philosopher of the second half of the 20th century, John Rawls. As well as having implications for resource allocation, John Rawls's work is of relevance to law and ethics in clinical practice, especially for psychiatrists, who often work with vulnerable, disadvantaged and stigmatised people.

In a civil society, when considering the effects of an act or rule or institution, we often have to consider choices between courses of actions that may have a good effect on some people but a bad effect on others. Such questions of distributive justice relate to decisions between conflicting interests. Political and ethical theory should give guidance on these matters. John Rawls (1921-2002), the foremost political philosophical theorist of social justice in the second half of the 20th century, set out his views on these matters in a series of papers and his important book A Theory of Justice (Rawls, 1971).

Social justice demands particular attention from psychiatrists and other mental health professionals. It is a fundamental aspect of citizenship and Rawls's writings inform the theories and practice of citizenship. An understanding of citizenship is essential both for the prevention of harm to psychiatric patients (Ikkos, 2002, 2004) and the effective provision of beneficent services to people with psychiatric disabilities (Sayce, 2000).

In this article we will present some of the key components of Rawls's writings and attempt to relate his theory of justice to clinical and policy

${ }^{\dagger}$ For a commentary on this article see pp. 211-213, this issue. considerations relevant to psychiatrists. Before doing this we will briefly summarise the liberal political philosophical tradition in which Rawls's views stand. Although we explain the terminology of political philosophy, in particular the concepts introduced by Rawls himself, as we mention it, Box 1 shows a glossary for quick reference.

\section{Political philosophical traditions}

Rawls's writings are part of a liberal tradition in political theory and of philosophical concerns with distributive justice and social contract theory.

Social contract theory relies on the fundamental idea that humans belong to one of two mutually exclusive states of (political) existence. In the 'state of nature' we enjoy natural rights such as our life, liberty and property. The alternative to living in a state of nature is to enter into 'civil society'. This move implies a 'contract' between its citizens, who have now willingly abandoned the state of nature and committed themselves to be stakeholders in the institutions of civil society and obey its laws.

Liberalism as a political theory is associated with social contract theory, but some social contract theorists offered illiberal political prescriptions. The distinguishing feature of liberal social contract

George Ikkos is Chair of the Royal College of Psychiatrists' London Division and Associate Medical Director of Barnet, Enfield and Haringey Mental Health Trust (Postgraduate Medical Education, Edgware Community Hospital, Edgware, Middlesex HA8 0AD, UK. Email: george.ikkos@barnet-pct.nhs.uk). He is also Chair of the Charing Cross General Professional Training Schemes in Psychiatry and Training Programme Director and Psychotherapy Training Coordinating Tutor of the Northern Sector of the schemes. Jed Boardman is consultant psychiatrist and senior lecturer in social psychiatry at the Institute of Psychiatry's Health Services Research Centre in London. He is Chair of the Faculty of General and Community Psychiatry, Royal College of Psychiatrists. He has chaired the College's Working Group on Employment Opportunities and Psychiatric Disability and acted as lead on behalf of the College during the parliamentary review of disability discrimination legislation. Tony Zigmond is a consultant psychiatrist and senior clinical lecturer in Leeds. He is Honorary Vice-President of the Royal College of Psychiatrists and leads on behalf of the College in matters relating to proposed changes in mental health legislation in England. 


\begin{abstract}
Box 1 A glossary of terms
Civil society Institutions and relations in society, especially society beyond government.

Difference principle Rawls's second principle of social justice, according to which society must be ordered so as to ensure best outcome for the least advantaged and allow equal opportunities for the participation of all in civil society.

Liberalism A philosophical tradition that places liberty at the heart of the social contract.

Liberty principle Rawls's first principle of social justice, according to which society must be ordered so that each individual has maximum possible liberty, provided that this is compatible with the liberty of others.

Maximin rule A rule adopted by Rawls, according to which rational individuals, in the original position, under a veil of ignorance, would wish to ensure that those worse off would benefit most in a society.

Original position A philosophical concept developed by Rawls to refer to the imagined position free individuals may be in a state of nature.

Priority rules The priority according to which principles of social justice must be applied in society. According to Rawls's first priority rule, liberty, as conceived in the liberty principle, takes precedence over all other considerations. According to Rawls's second priority rule, fair opportunity takes precedence over the difference principle and the difference principle takes precedence over efficiency.

Social contract A philosophical concept, whereby individuals in a state of nature come together and agree to form a society on the basis of an explicit contract

State of nature A philosophical concept, whereby individuals are assumed to live free outside any society.

Veil of ignorance A philosophical concept developed by Rawls, whereby free individuals, in a state of nature, in the original position, discuss the principles of the social contract without prior strength of their position, strengths or weaknesses or goals in society. This is so as to ensure rational principles in the face of the assumed selfinterested nature of humans.
\end{abstract}

theories is that they consider that those moving from a state of nature to become stakeholders in a civil society must be offered convincing justifications before accepting civil society and the restrictions that state authorities may place on their liberty.

\section{Rawls's theory of social justice Assumptions}

Two assumptions underlie Rawls's theoretical position. First, his basic view of humans was that they have the capacity to reason from a universal point of view and thus have the capacity to judge principles from a moral standpoint. Second, his main concern was that there should be no overall subordination of the interests of some to the interests of others and that the accepted rules on which justice is based are fair. His views can thus be conceived as 'justice as fairness' (Rawls, 2001). This is in contrast to utilitarian political philosophers, who may be willing to sacrifice the interests of the few to increase the happiness of the many.

In the context of the above assumptions, the main elements of Rawls's theory are threefold: the original position, the basic principles and the priority rules.

\section{The original position}

Rawls imagines persons in the hypothetical situation of the 'original position', in which the moral and political point of view is discussed with impartiality and in which we can discover the nature of justice and the requirements of individuals and institutions that aid cooperation. In the original position he places on people the limitation of the "veil of ignorance'. This denies them knowledge of such things as their circumstances (e.g. gender, ethnicity), their conception of what makes the 'good way of life', and the state of society. Thus, they can choose the principles for a just society from initial conditions that are inherently fair. 
The original position can be seen as an abstract version of the state of nature. In this imagined state we are all equal in being outside civil society and having no preconception about our position in that society. Therefore we may rationally discover fair principles of justice and what these require of individuals and the social institutions through which we live in a cooperative manner. In this original position, the people are:

- all in the same situation and everyone is assumed to be equally rational and disinterested in one another's well-being;

- self interested - they are not impartial and their aim in choosing principles is to do as well for themselves as they can;

- ignorant - they are not allowed to know what arrangement favours them over others (this restricts their self-interest);

- cautious - they play safe in their judgements.

One difficulty with this situation is that there must be some preceding state in which the people in the original position decide on the features of the situation in which the principles of justice will emerge. For example, Rawls assumes that everyone is entirely self-interested and ignorant of their own and others' bargaining strength.

The principles of justice are thus those that anyone would favour, given certain desires and information.

In setting up the original position, Rawls is guided by a set of values and these are based on an intuitive stance that certain moral principles are self-evident or axiomatic. In Rawls's case these are:

- inequality: inequality is morally objectionable and, therefore, in need of justification if it is to be allowed; this is an example of prima facie egalitarianism (see below);

- natural endowment: people should not get more simply because of some accident of birth;

- liberalism: the holding of traditional liberal ideals of such things as freedom of religion and conscience. These lie behind the setting up of the veil of ignorance. Rawls wishes the people in the original position to choose liberal values.

\section{Basic principles}

Placing individuals behind the veil of ignorance, Rawls proposes two principles of justice to be used in the original position:

'First principle: Each person to have an equal right to the most extensive system of equal basic liberties compatible with a similar system of liberty for all.
Second principle: Social and economic equalities are to be arranged so that they are both:

a. To the greatest benefit of the least advantaged, consistent with the just saving principle.

b. Attached to offices and positions open to all under conditions of fair equality of opportunity' (Rawls, 1971: p. 302).

Consider the consistency of these principles with the methods of the original position set out above. The second principle is supported by the method, as behind the veil of ignorance we do not know our situation in society but we will only accept principles that will be to our advantage.

The first principle is called the 'liberty principle'. Part ' $a$ ' of the second principle is important and Rawls calls this the 'difference principle'. It illustrates why Rawls's view on equality is one of prima facie egalitarianism. He believes not that inequality is always morally objectionable (a conclusive stance), but that it may only occur with good reason (a prima facie or defeasible objection); hence his 'general theory of justice':

'All social primary goods - liberty and opportunity, income and wealth, and the bases of self-respect - are to be distributed equally unless an unequal distribution of any or all of these goods is to the advantage of the least favoured' (Rawls, 1971: pp. 302-303).

As with other theorists concerned with distributive justice, Rawls accepts that there may be inequalities, as these provide incentives, but suggests that the degree of inequality must be shown to be that necessary to achieve a high level of welfare for the least advantaged group. Rawls asks that our social arrangements be evaluated from the standpoint of those who are worst off.

These principles of justice constrain the social contract (for example by setting out what the constitution and laws can require of us) and set the limits on how we can construct a civil society.

\section{Priority rules}

Rawls also delineates two 'priority rules' to guide decisions in relation to the application of his principles:

'First Priority Rule (The Priority of Liberty): The principles of justice are to be ranked in lexical order and therefore liberty can be restricted only for the sake of liberty.

Second Priority Rule (The Priority of Justice over Efficiency and Welfare): The second principle of justice is lexically prior to the principle of efficiency and to that of maximizing the sum of advantages; and fair opportunity is prior to the difference principle' (Rawls, 1971: 302-303). 
The two principles of justice set out in the previous section are thus related to each other by a specific order (what is referred to above as 'lexical order') and the demands of the first must be satisfied before the second can be tackled. This suggests a preference for certain kinds of social goods over others, for example those concerned with civil liberties over those concerned with economic advantage. So we cannot choose to go without some of our civil liberties in search of greater economic advantage. Similarly, the statement that 'fair opportunity is prior to the difference principle' (p. 303) makes it clear that loss of equality of opportunity is unacceptable, even if such loss would raise the welfare of those worse off in society.

Rawls's concept of liberty (or freedom) is both positive (freedom to do) and negative (freedom from). His 'general' conception of liberty is contained in the difference principle, and his 'special' conception in the priority rules. He does not see circumstances such as poverty as violating liberty, but rather diminishing the worth of liberty to the person who is poor.

\section{Making decisions in the original position}

We have set out above some of the assumed charact eristics of the assumed candidates to be future stakeholders/citizens in a civil society and the principles and priority rules that guide their decision-making, according to Rawls. Let us consider in more detail how decisions are made in the original position.

\section{Ignorance}

Behind the veil of ignorance the people are ignorant of the particular state of society, their particular circumstances (e.g. gender, ethnicity) and the primary goods (health, physical strength, natural resources, influence, authority) that are useful in pursuing a wide range of objectives. They are also ignorant of their conception of the good (their values - beliefs about religion, politics, etc.). Given this degree of ignorance, how can decisions be made in the original position, how can people judge whether they get the best share they can of the primary goods (which is no more than a fair share, given their equality in the original position)?

Part of the answer to this is that some primary goods may be useful for furthering certain objectives that people may have in the original position, for example an interest in developing an effective sense of justice or rational creation of a sense of the good. These higher-order interests are the ones that operate in the original position, and liberty is seen as what we need most (after conditions of physical survival have been given) to pursue our goals or 'plan of life'.

\section{Cautiousness}

Since in the original position people are ignorant, they are making decisions under conditions of uncertainty. But they must try to get the best deal for themselves. Here Rawls operates as a game theorist, asking people to adopt a strategy that any rational person would adopt in the particular situation.

There are several scenarios for play in game theory, the most familiar being the Prisoner's Dilemma (where non-cooperation and the pursuit of self-interest by two parties makes them both worse off). But consider the situation where you wish to design rules for cutting a cake. You may consider cutting it into unequal slices, but in doing so you risk ending up with a small slice. A more rational (and, from the point of view of the result, fair) option would be to cut the slices equally, so that you guarantee yourself the largest slice you can get under the circumstances. This decision policy is called the maximin rule: you maximise your minimum return. It is a cautious rule that can be adopted (by cautious maximisers) to get the best of all the possible worst results.

This maximin rule operates behind the veil of ignorance and makes the lowest social position as good as possible - it aims at social equity. It also applies to the difference principle, as cautious maximisers may accept a rule that results in social inequity, if it will make being in the worst position better than it would otherwise have been.

\section{Lifting the veil of ignorance in stages}

The people in the original position may be both drawing up rules about the structure of society and planning a society. But to move from one to the other it is necessary to lift the veil of ignorance in stages, to allow in more information about matters such as the historical circumstances of the society under consideration, thus allowing rules of justice to be decided upon before a constitution is drawn up and before laws and policy are decided.

\section{Individual justice}

In addition to its implications for civil institutions, Rawls is also concerned with what justice requires of us as individuals.

He distinguishes between obligations and duties. He considers that, in the original position, individuals will accept principles requiring the discharge of these. 
Obligations are seen as arising out of some voluntary act (e.g. a promise), whereas duty is something that one owes, separate from any voluntary undertaking (e.g. to save someone from danger).

The main principle underlying obligations is that of 'fair play', which means that if you have voluntarily accepted benefits, then you ought to benefit others and play your part, even at a cost to yourself. In terms of the 'general theory of justice', the more-gifted individuals in society cannot benefit from their talents, except on condition that these also benefit the worst off.

Rawls's main concern for duties is that individuals are expected to support the establishment and maintenance of just social institutions. Conversely this allows for civil disobedience, when social institutions are unjust.

\section{Relevance of Rawls to psychiatry}

\section{Autonomy}

Respect for autonomy (in this context, respect for self-determined choice in healthcare) is a commonly accepted fundamental principle of medical practice (Gillon, 1994; Ikkos, 2004). In the UK, the priority given to autonomy by the courts and in proposed mental capacity legislation (Department of Constitutional Affairs, 2004) is consistent with Rawls's liberty principle.

Rawls's approach, along with current and proposed legislation, suggests that actions on the part of psychiatrists that curtail patient autonomy cannot be accepted at face value and must be justified on each occasion. Our patients, as fellow citizens joining us in a social contract in a liberal society, can expect us to presume their autonomy in all cases.

Many autonomous individuals who retain full decision-making capacity make decisions that, to some or the majority of others, seem irrational. As Dame Butler-Sloss said in the case of Ms B (Ms B v An NHS Trust, 2002):

\footnotetext{
'a competent patient has an absolute right to refuse to consent to medical treatment for any reason, rational or irrational, or for no reason at all, even when that decision may lead to his or her death'.
}

How can this be reconciled with Rawls's assumption of universally accepted rationality?

One approach would be to consider that, when Rawls refers to rational, decision-making individuals in the original position (acting under the veil of ignorance), he does not refer to real individuals but to abstract individuals. Such abstract individuals, reasoning rationally, Rawls contends, would reach an agreement that the right to make irrational decisions should prevail, even when such decisions may lead to death. Respect for autonomy is directly related to the liberty principle and not to rationality. It is the liberty principle itself, and not autonomous decision-making, Rawls would argue, that stems from rational argument.

\section{Psychiatric disorder and the loss of autonomy}

As Rawls's approach is consistent with a presumption of autonomy for those with psychiatric disorder, it represents an advance over the position of some of his predecessors. Aristotle (1998 reprint), for example, routinely appears to refer to 'madness' as a criterion for excluding those with mental illnesses from his considerations. The progress from Aristotle to Rawls may be reflected in some of our own legislative advances, as only recently has it been recognised that mental illness, including detention under the Mental Health Act 1983, is not synonymous with incapacity to make decisions. All adults are now permitted to vote unless they lack capacity (or are convicted criminals).

\section{The psychiatrist's task}

Although autonomy may be presumed initially, in some cases it will be possible to demonstrate that it has been lost (or never been there for those with severe and enduring psychiatric disorder starting before the age of 16). Autonomy may be lost through cognitive impairment caused by head injury, or disturbance of thinking/feeling/perception caused by functional psychiatric disorder. Tan has also proposed that autonomy may be lost through what she has termed 'pathological values' arising directly out of psychiatric disorder (J. Tan, personal communication, 2005). From the point of view of Rawls, the important issue is not whether autonomy may be lost; it clearly can. The important point is that in each case that the psychiatrist asserts the loss of autonomy, he or she must be able to demonstrate the loss convincingly. Furthermore, to the extent that psychopathology leads to loss of autonomy (and therefore liberty) because of the impairment of mental capacity that it causes, Rawls's theory would suggest that a psychiatrist should not only be in a position to demonstrate such impairment, but should also actively seek to investigate the issue, where such impairment is suspected.

If the priority given by Rawls to liberty is accepted, then the identification of incapacity and restoration of capacity for autonomous decision-making must be given high priority. Where restoration of capacity is limited or not possible, we need to accept and respect people's dependency and provide fair 
ways of acting for them, such as the provision of advocacy services.

\section{Revised legislation}

The Mental Capacity Act 2005 is explicit in requiring, among many other things, that a person must be assumed to have capacity, unless it is established that he or she lacks capacity. Individuals are not to be treated as unable to make a decision unless all practicable steps to help them to do so have been taken without success, and they are not to be treated as unable to make a decision merely because they make an unwise decision. Furthermore, an action taken or decision made under the Act for or on behalf of a person who lacks capacity must be in that person's best interests, and the psychiatrist must consider beforehand whether the purpose for which it is needed can be as effectively achieved in a way that is less restrictive of the person's rights and freedom of action. The Act makes provision for the appointment of independent mental capacity advocates.

\section{Psychiatric disorder and the restriction of liberty}

Rawls advocates that liberty can be restricted only for the sake of liberty. This may be for the sake of liberty of the individual restricted or the liberty of others. Can this approach inform us about crucial aspects of the proposal for a new Mental Health Act for England and Wales, as described in the draft Mental Health Bill (Department of Health, 2004a)? The Joint Committee scrutinising the draft Mental Health Bill stated that:

'The legislation should take greater account of a person's ability to make decisions about his treatment. We recommend that a new condition be met before compulsory powers can be used which is that a person's ability to make a decision about accepting treatment is significantly impaired as a result of mental disorder. Where a person's decision making is unimpaired, he should be able to reject the treatment' (House of Lords \& House of Commons Joint Committee on the Draft Mental Health Bill, 2005: p. 5).

It appears therefore that the Joint Committee is criticising the government for not applying the liberty principle (and its corollary: respect for autonomy) and advises closer attention to these.

In addition, the Committee recommends that the possible threat to the public from people with dangerous and severe personality disorder be dealt with through separate legislation. It explicitly states:

'the primary purpose of mental health legislation must be to improve services and safeguards for patients and to reduce the stigma of mental disorder' House of
Lords \& House of Commons Joint Committee on the Draft Mental Health Bill, 2005: p. 5),

and seems to suggest that government proposals run contrary to such priorities.

Here the Committee seems to accept the view that the restoration of autonomy through identification and treatment of incapacitating illness should be the highest priority in terms of service provision for those with psychiatric disorder. This is consistent with Rawls's theory of justice. When considering mental health legislation in the original position, not knowing whether we might be affected by psychiatric disorder and adopting the maximin approach, we would wish such legislation to give priority to ensuring the best treatment for mental disorder and not to other considerations.

There may be grounds for detention and treatment of people without impaired mental capacity, for the protection of others, but this is a public order matter and is better dealt with through public order and not mental health legislation. Under mental health legislation, there can be no mental health justification for the compulsory detention and treatment of people with psychiatric disorder in the presence of mental capacity.

\section{Liberty, psychiatric disorder and human rights legislation}

Rawls regards liberty not as a general free for all but in terms of civil liberties, for instance the right to vote, to run for office, due process, free speech and mobility. This is consistent with human rights legislation.

The Human Rights Act 1998 brings the European Convention for the Protection of Human Rights and Fundamental Freedoms into British law. Two articles of the European Convention are of particular relevance to psychiatry. The first is Article 2(1):

'Everyone's right to life shall be protected by law.'

That is, the state has a duty to protect life in addition to not removing it. Where threat to the life of the patient or another arises out of disability and impairment of capacity due to psychiatric disorder, psychiatrists have an obligation to act consistent with Article 2.

Rawls's principles may be useful in helping us balance the advocating of restricting liberty in order to ensure protection of others and not conferring any likely benefit to the patient. Consider the second Priority Rule (the priority of justice over efficiency and welfare), the corollary of which is that justice demands that coercion must not replace the provision and proper resourcing of services. The notion of justice, as advocated here, is reflected in the European Convention and the Human Rights Act 
1998 in the notion of 'proportionality'. That is, any restrictions placed on a person must be proportional to the risks presented. A utilitarian approach that favours efficiency over justice would lead to the opposite conclusion.

The second is Article 5(1)e:

'Everyone has a right to liberty and security of person. No one shall be deprived of his liberty save in the following cases and in accordance with a procedure prescribed by law:

(e) the lawful detention of persons for the prevention of spreading of infectious diseases, of persons of unsound mind, alcoholics, drug addicts or vagrants'.

The European Convention refers only to the 'deprivation of liberty', which gives a high threshold. The recent judgment in relation to the case of $\mathrm{Mr} \mathrm{L}$ (the 'Bournewood case'; Department of Health, 2005) made it clear that Article 5 of the Convention is breached only if all rights and freedoms are removed from the individual, i.e. the state takes complete control. Detaining a person in hospital, so long as it is associated with a care plan, a review process and permission to remain in contact relatives, would not amount to deprivation of liberty.

In interpreting Article 5 we are faced with a gradual lifting of the veil of ignorance and moving forward from an agreed abstract liberty principle to its application to real individuals in concrete historical societies in a manner consistent with an understanding of liberty as civil liberties. The legislators and courts are necessarily involved in setting out the issues and making the rules to govern our behaviour with respect to this.

\section{The difference principle and disability}

People with mental illnesses are considered to be among the socially excluded and this is officially recognised in government policy (Office of Deputy Prime Minister, 2004). The relevance here of Rawls's ideas lies in the difference principle, which is asking us to evaluate our social arrangements from the standpoint of the disadvantaged; in this case, those with disabilities in general and those with disabilities relating to their mental condition in particular. This may form the basis of our stance on the need to alter the position of individuals with mental illnesses and those with learning disabilities (we may also include people with personality disorders here) and to ensure that the policies are just and to their benefit. The relevant policy areas are those of pathways to work, provision of welfare benefits and discrimination. An example of how this may work in practice is given in Box 2 .

\section{Box 2 Amending discriminative legislation}

The Disability Discrimination Act 1995 applied to people with disabilities associated with physical and mental disorders. The Act contained components that did not apply equally to people with these disorders. For example, under the definition of disability, people with mental disorders had to show that their disorder was 'well recognised', a condition that did not apply to those with physical disabilities. This added an extra burden to those with mental disorders and provided an additional barrier not present for those with physical disorders, and thus was unfair. Following objections by organisations representing the interests of people with mental disorders this clause was removed from the revised Disability Discrimination Act 2005.

These aspects of distributive justice may also inform our arguments about resource allocation. For example, standards in mental health services fall below those in the rest of the National Health Service, despite the clear advances in treatment and provision of services over the past 20 years. In 2003-2004, mental health trusts were more likely than acute trusts to receive a zero star rating in assessments (Healthcare Commission, 2004). Funding for mental health services remains low and poorly distributed (Department of Health, 2004b). The National Service Frameworks have been brought in with the associated promise of increased spending on the health service as a whole and mental health services in particular, but the increased funding may not have been reaching local services (Sainsbury Centre for Mental Health, 2003).

More broadly, improvements in health seen in the 20th century have not been shared equitably, within or across countries. Rawls's philosophy would support the contention that when the capacity exists for generating social goods that enhance health for some, then it is only fair to distribute that capacity to all. This can be seen in work on social inequality and social capital (Wilkinson, 1996).

\section{The social basis of self-respect}

Rawls gives high priority to liberty and views selfesteem as an important primary good. The link he makes here is:

'the basis for self-esteem in a just society is not... one's income share but the publically affirmed distribution of fundamental rights and liberties' (p. 543) ... 'the public affirmation of the status of equal citizenship' (p. 545). 
The social bases of self-respect are important primary goods and are seen by Rawls as important in pursuing our personal ends or 'plan of life'.

Implicit in Rawls's writings is the notion that certain inequalities are unavoidable, in particular those related to abilities and talents and the differential status associated with family, class and so on. These inequalities raise important questions about fairness and justice and come together under the umbrella of citizenship. Following from the social exclusion argument introduced above, it is important that rights of citizenship are given to people with mental illnesses and that these are distributed fairly and allow access to justice. But how might this be understood in real terms of relevance to psychiatry?

Sennett (2003) gives some clues when he considers respect and what this might mean in conditions of inequality. He outlines three modern codes of respect-make something of yourself, take care of yourself and help others - all of which he believes are blemished by inequalities. His answer to our question is that psychiatrists should honour practical achievements, admit just claims of adult dependency and allow people to participate more actively in their own care.

For Rawls, respect is related to mutuality, which implies recognition of others and, in his terms, means respecting the needs of those who are unequal. In psychological terms this may be reflected in the idea of autonomy, which in this case means accepting in others what one does not understand about them. In so doing, we treat their autonomy as equal to our own. From the stance of the work of mental health professionals a view of social justice for those who may be chronically disadvantaged is crucial:

'In society, and particularly in the welfare state, the nub of the problem we face is how the strong can practice respect towards those destined to remain weak' (Sennett, 2003: p. 263).

This is related to what Rawls names his Aristotelian principle, which is concerned with equal human beings enjoying the exercise of their realised capacities 'and this enjoyment increases the more the capacity is realised, or the greater its complexity' (Rawls, 1971: p. 414). Here Rawls is suggesting that there is a positive circle between proficiency and pleasure, which may be seen in the creation of access to open employment, a component of citizenship and social inclusion (Boardman, 2003).

This aspect of Rawls may be seen to inform, or form the basis of, our political and moral views on mental health promotion and the value of meaningful activity in mental health.

\section{Doctors as public servants: using talents}

In his views on individual justice, Rawls places emphasis on fair play and considers the use of talents for the benefits of others. This places an obligation on psychiatrists as 'talented' clinicians and on our institutions to work for the benefit of the less able. The component of mutual respect has been discussed, but the onus is placed on psychiatrists to assist in furthering social justice for those with psychiatric disabilities at an individual and institutional level. This approach to social justice may be an advance for our thinking about more archaic notions of altruism and vocation.

\section{Conclusions}

Any one political theory is unlikely to be adequate as a complete framework for psychiatric practice. Psychiatrists, as citizens practising medicine with vulnerable individuals in extreme situations, need to be familiar with diverse political perspectives (Box 3). It is the complex picture emerging from dialogue between different perspectives that is most likely to underpin best clinical practice and social policy (Ikkos, 2002).

Rawls has been criticised by political philosophers of a variety of persuasions, including the libertarian (Nozick, 1974), egalitarian (Miller, 1999; Dworkin, 2000), communitarian (Sandel, 1982; Etzioni, 1995), Catholic (Taylor, 1999) and feminist (Mackinnon, 1987). Although Rawls's theory is open to criticism, it is of immense value. His emphasis on individual liberty and profound concern for the vulnerable individual defines certain limits in relation to the liberty and welfare of these people that we should not transgress in our practice as individual clinicians and employees of the state. Conversely, if we propose to, then we have to make an explicit, strong and justifiable case for each such transgression. John Rawls has attempted to set clear standards by which our justifications may be judged.

\section{Box 3 Suggested further reading}

- Kymlicka, W. (2002) Contemporary Political Philosophy: An Introduction (2nd edn). Oxford: Oxford University Press.

- Roberts, P. \& Sutch, P. (2004) An Introduction to Political Thought. Edinburgh: Edinburgh University Press.

- Woolf, J. (1996) An Introduction to Political Philosophy. Oxford: Oxford University Press. 


\section{Declaration of interest}

None.

\section{References}

Aristotle (1998 edn) Nichomachean Ethics. Oxford: Oxford University Press.

Boardman, J. (2003) Work, employment and psychiatric disability. Advances in Psychiatric Treatment, 9, 599-603.

Department of Constitutional Affairs (2004) Mental Capacity Bill: Draft Code of Practice. London: Department of Constitutional Affairs.

Department of Health (2004a) Draft Mental Health Bill (Command 6305-1). London: Department of Health.

Department of Health (2004b) The National Service Framework for Mental Health - Five Years On. London: Department of Health.

Department of Health (2005) "Bournewood" Consultation. The Approach to be Taken in Response to the Judgement of the European Court of Human Rights in the "Bournewood" Case. London: Department of Health.

Dworkin, R. (2000) Sovereign Virtue: The Theory and Practice of Equality. Cambridge, MA: Harvard University Press.

Etzioni, A. (1995) The Spirit of Community London: Fontana.

Gillon, R. (1994) Medical ethics: four principles plus attention to scope. BMJ, 309, 184-188.

Healthcare Commission (2004) NHS Performance Ratings 2003-4. London: Commission for Health Care Audit and Inspection.

House of Lords \& House of Commons Joint Committee on the Draft Mental Health Bill (2005) Draft Mental Health Bill, Session 2004-05. Volume I (HL Paper 79-I, HC 95-I). London: TSO (The Stationery Office).

Ikkos, G. (2002) Using 'citizenship' to deal with feelings of hate in psychiatry. Hospital Medicine, 63, 471-475.

Ikkos, G. (2004) Clinical hate and political forgiveness. Psychiatriki, 15, 17-26.

Mackinnon, K. (1987) Feminism Unmodified: Discourses on Life and Law. Cambridge, MA: Harvard University Press.

Miller, D. (1999) Principles of Social Justice. Cambridge, MA: Harvard University Press.

Nozick, R. (1974) Anarchy, State and Utopia. Oxford: Blackwell.

Office of Deputy Prime Minister (2004) Mental Health and Social Exclusion. Social Exclusion Unit Report. London: Office of Deputy Prime Minister.

Rawls, J. (1971) A Theory of Justice. London: Oxford University Press.

Rawls, J. (2001) Justice as Fairness. Cambridge, MA: Belknap Harvard.

Sainsbury Centre for Mental Health (2003) Money for Mental Health. London: Sainsbury Centre for Mental Health.

Sandel, M. (1982) Liberalism and the Limits of Justice. Cambridge: Cambridge University Press.

Sayce, L. (2002) From Psychiatric Patient to Citizen: Overcoming Discrimination and Social Exclusion. Hampshire: Palgrave.

Sennett, R. (2003) Respect. The Formation of Character in an Age of Inequality. London: Penguin Books.

Taylor, C. (1999) A Catholic Modernity. Oxford: Oxford University Press.

Wilkinson, R. G. (1996) Unhealthy Societies. The Afflictions of Inequality. London: Routledge.

Ms B v An NHS Trust [2002] 2 All ER 449.

\section{MCQs}

1 In the original position:

a people are operating behind a veil of despair

b people, if rational, should arrive at just principles

c people are impartial

$\mathrm{d}$ people are cautious

e people look at moral principles in a strict lexical order.
2 For people with mental disorder:

a the difference principle proposes that they be debarred from voting

b autonomy means that removal of liberty can be done without recourse to consent

c the difference principle suggests that they should have fair access to resources

d the fair distribution of fundamental rights may be a basis for self-esteem

e the enjoyment of realised capacities may increase happiness.

3 Rawls's liberty principle underpins the following:

a the presumption of mental capacity as required by the Mental Capacity Act 2005

$\mathrm{b}$ the right of capacitous patients to make irrational decisions

c the notion of proportionality as used in the Human Rights Act 1988

$\mathrm{d}$ risk being the basis of compulsion under the draft Mental Health Bill

e granting the right to vote for detained patients (unless convicted by the courts).

4 The following statements represent Rawls's views:

a inequality is always wrong

b efficiency should take priority over equality in health service provision

c we should judge the merit of a civil society from the point of view of the most vulnerable

$\mathrm{d}$ the difference principle implies that those with better natural endowments should have more respect in society

e citizens who have voluntarily accepted social benefits are obliged to benefit others and play a part in society, even at a cost to themselves.

5 According to Rawls's liberty principle:

a people should never be detained under the Mental Health Act

b people with disorders related to substance misuse are making a free choice

c social exclusion of people with mental illnesses is necessary to preserve the liberty of others

d unemployment among those with psychiatric disorder is a matter of free choice

e each person should have equal access to the most extensive system of equal basic liberties.

\section{MCQ answers}

\begin{tabular}{|c|c|c|c|}
\hline 1 & 2 & 3 & 4 \\
\hline a $F$ & a $F$ & a $\mathrm{T}$ & a $F$ \\
\hline b $\mathrm{T}$ & b F & b $\mathrm{T}$ & $b F$ \\
\hline c $\mathrm{F}$ & c $\mathrm{T}$ & c $\mathrm{T}$ & c $\mathrm{T}$ \\
\hline $\mathrm{d} T$ & $\mathrm{~d} T$ & d F & d F \\
\hline e $F$ & e $\mathrm{T}$ & e $\mathrm{T}$ & e $\mathrm{T}$ \\
\hline
\end{tabular}

